\title{
The Farm Credit Crisis: Will It Hurt the Whole Economy?
}

\author{
Michael T. Belongia and R. Alton Gilbert
}

19 OMl economists estimate that 5 percent or more of all fams cumently in business will go into bankruptcy in 1986, and that one farm in sevet will fail within the next four vears. A recent sudy ty two agriculfual economists estimates that farm lenders may write of as much as $\$ 50$ billion in bad fam debt over the next fou vears, with $\$ 20$ billion cited as the "most probable" loss estimate."

Such projections of losses on fam loans mav be high. Nevertheless, actual losses to date already have been large enough to cause a substantial increase in the fallue wate among agriculumal bakks. Accounting for 22 percent of bank fallues between 1981 and 1983. agricultumal banks have made up aboul two-thirds of all faled banks since July 1984: 62 agnicultural banks failed during 1985. Moreover, the Fam Credit Svstem. a group of federally sponsored agencies that lends to farmers, amnounced this fall that it will need diect assistance from the federal government to stay in operalion."

Ordinarily, the failure of some famers and some fan lenders need not attract more altention than we

Michael $T$. Belongia is a senior economist and R. Alton Gibert is an assistant vice president at the Federal Reserve Bank of St Louis. Laura A. Prives provided research assistance.

Schink and Urbanchuk (1985), Drabenstott and Duncan (1985), and "The Farm Slide" (1985).

aschink and Urbanchuk.

${ }^{3}$ Agricultural banks are identified as those with a fatio of farm loans to total loans above the national average for all commercial banks. This average is currently 17 percent.

"Karr and McCoy (1985). For a discussion of the financial condition of farm lenders, see Belongia and Carraro (1985) curently pay to the thousands of business fims that fail each year. "For several reasons, however, the carrent farm debt situation has attracted special atlention. Fist, projections of large losses concentrated in agriculture have ereated concen about the econonic health of the entire industry. Moreover, the farm credit crisis has developed at a time when loan losses of commerial banks already are relatively high. finally, the apparent whinerability of the banking svstem to the farm credit crisis has increased public concen about the continued vability of many banks that have been heavily committed fo agricultumal lending.

Some economists futher believe that problems in the farm sector will spill over into the rest of the economy, causing slower economic growtl and lower employment. One recent study suggested that bank failues resulting from losses on farm loans contel calse investors to riew investments in all privately issued securities as more risky Consequently, interest rates on all privalely issued securties could rise relative to the interest rates on U.S. Treasury securities. causing a slowing in economic growth. This article discusses reasons for thinking that this effect either will not occur or will be relatively insignificant and or short-lived.

5From 1979 through 1984, an average of 20.000 business firms failed each year. U.S. Department of Commerce (1985).

'Schink and Urbanchuk. in particular, the Wharton study indicates wider spreads between the commercial paper rate and the threemonth Treasury bill rate. A related study by Chase Econometrics (1985) deals with the more narrow question of a defaut by the Farm Credit System on its bonds. Its study shows even more substantial spillover effects, with private debt interest rates rising by $300-$ 400 basis points over rates on government debt. 
Chart 1

\section{Farm Land Values and Farm Debt}

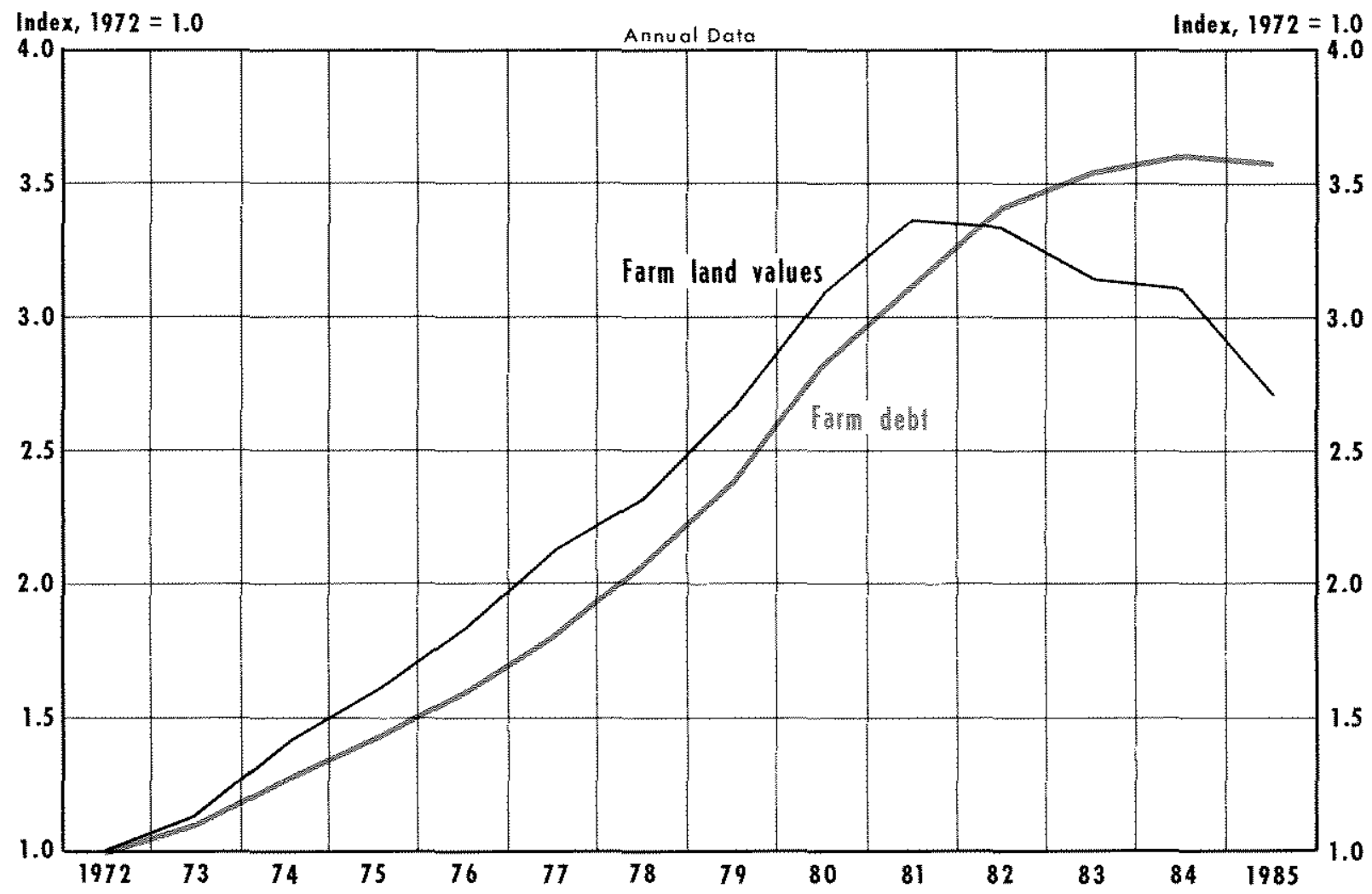

If the failure of large numbers of farms affects both interest rates and general economic activity adversely, then assisting the agricultural sector of the economy may make sense over and above the usual rationale based on the social benefits of maintaining the family farm. The magnitude of federal aid necessary to keep farm lenders viable, however, has been estimated to be in the "multi-billions" of dollars for the Farm Credit System alone. In light of current efforts to reduce the federal budget deficit, it seems prudent to assess the likelihood that the current financial problems of the farm sector will affect the whole economy adversely.

This article analyzes the influences of the curent farm credit crisis on the economy in two ways. The first approach examines the performance of financial markets and the economy in recent vears. Since the financial trouble of famers became widespread after the average price of farmland started declining in 1981 , we might expect to observe some adverse effects on the economy already. The second approach examines the effects of the farm financial crists of the $1920 \mathrm{~s}$ on the economic activity of that period.

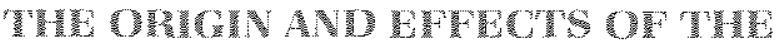

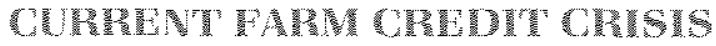

Today's farm crisis developed as a result of the rapid increases in the prices of farmland in the 1970s through 1981 and the subsequent declines in land prices since then. The 1970 s and early 1980 s were years of rapid inflation. From 1972 through 1981 , the GNP deflator rose at an 8.1 percent average annual rate while the CPI rose at a 9 percent average rate. The price of farmland rose even more rapidly: the average price of an acre of farm real estate cose at a 14.4 percent anmual late from 1972 through 1981

Chart 1 indicates that total fam debt rose in step with the rise in the prices of farmland. Movements in

'Between 1972 and 1981 . the price of farmand increased at an average annual rate of 14.4 percent, while, over the same period, total farm debt increased at a 13.5 percent average annual rate. 
Chart 2

\section{Farm Land Values and Prices Received by Farmers}

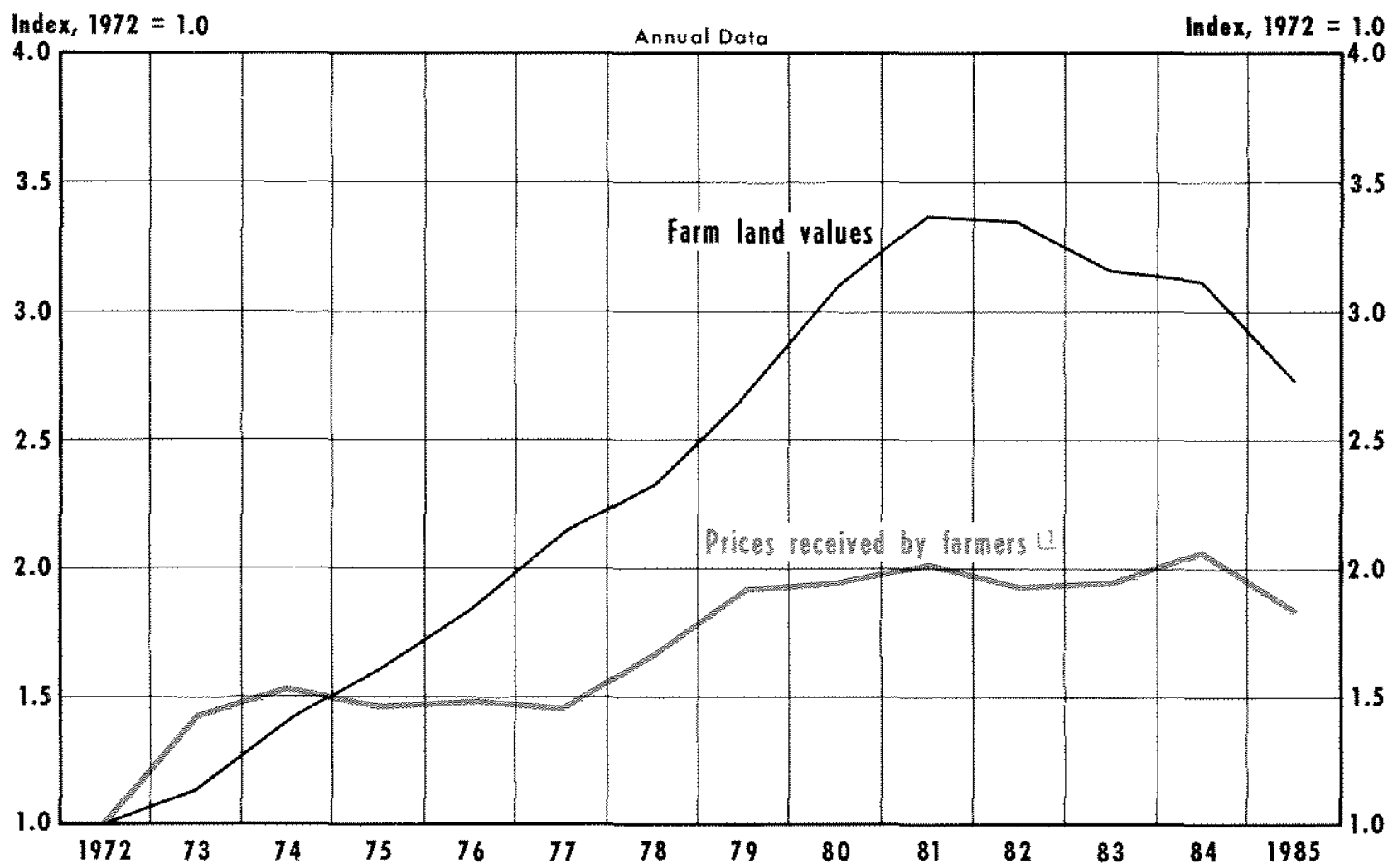

land prices and farm debt ove this period were closelv related for two reasons: First many farmers who bought land while land prices were rising botrowed heavily to finance then purchases. Second the rising land prices enabled famers to pledge their land as collateral for general purpose loans.

Unfortunately for farmers, prices of farm commodim ties did not rise as fast as farmland prices (chart 2 ). From 1972 through 1981, an index of prices received by farmers on all farm products rose at an 8.1 percent rate, equal to the general inflation rate. Furthermore, most of the rise in the index of farm prices over these years was concentrated in $1973-74$ and $1978-79$. Prices received by famem have not risen as rapidly as the GNP deflator since 1979 . Thus, during the vears of rapid inflation, the price of farmand rose substantially faster than the prices received by farmers for their output.

The general rate of inflation slowed shaply afte:
1981. making famland ownership less valuable as an inflation hedge. In addition, the price of farm otutput relative to nonfarm prices has dedined by 1.8 percent since 1981. For manv famers who borrowed heavily during the period of rapid increases in the price of farmand prices received for fam products have not been high enough to cover their operating expenses and meet their loan pavments. Consequenty fam lenders have begun incuming losses on the toans on which farmers have defalted, and the protection of collateral for fam lenders has been eroded by falling farmland prices.

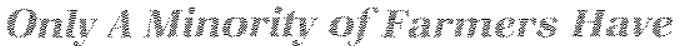

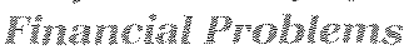

The data in table 1 show that the "fam credit crisis" is concentrated primarily among a minority of the family-size commercial farms. which have annual 


\section{Table 1}

\section{Distribution of Family-Size Commercial Farms by Their Ratio of Debt to Assets, January 1985}

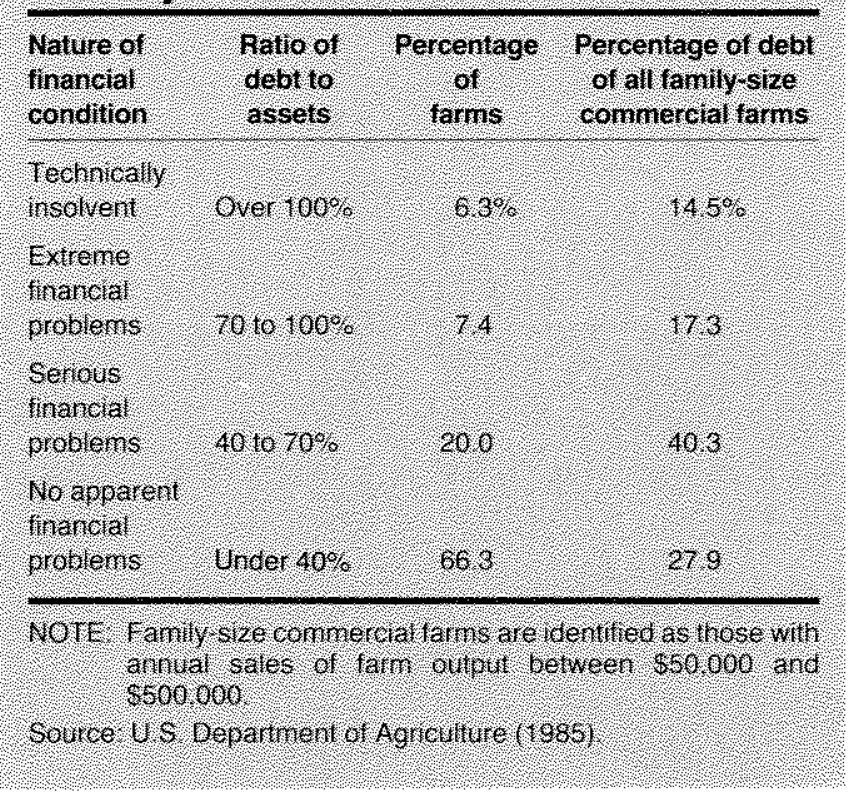

sales of farm output between $\$ 50.000$ and $\$ 500000$. About two-thirds of the family-size commercial tams have ratios of debt to assets below 40 percent: the LSDA considers these farms to have no apparent financial problems. Moreover, these farms accom for less than 30 percent of the debl hele by medium-size fams. In contrast about 14 percent of family-size commercial fams have debt-to-assets matios of to percent or higher, and these account for over 30 percent of the debt. In lotal about one-hird of family-size

8Farms with less than $\$ 50,000$ in annual sales tend to be part-time operations for the farmers: for these farms. there are nonfarm sources of income available to meet the debt payments. In contrast, many of the farms with annual sales over $\$ 500,000$ are specialty operations, like cattle feedlots and poultry farms, which have opefated profitably with high debt-to-assets ratios for many years. Farms with relatively large annual sales tend to be more profitable than smaler farms.

Only 1 percent of all farms have sales in excess of $\$ 500,000$ but they account for more than 60 percent of farm income. In contrast. the group of farms with less than $\$ 40,000$ in annual sales actually shows a toss equal to 6.5 percent of farm income.

In comparing farms that sell between $\$ 40,000$ and $\$ 500,000$ of product annually with those selling mote than $\$ 500,000$, the larger farms have an income-to-equity ratio of 16.5 and an income-to-debt ratio of 28.6 vs. figures of 3.3 and 11.9 , respectively, for the smaller category of commercial-size farms. For more detail on holdings of farm debt by size of farm and alternative estimates of the number of farms in serious financlal trouble, see Bullock (1985). commencial fams loold more than 70 percent of this farm category's debt and have deblo-assets malos that indicate some financial stress. It is this minority of farmers - and their lenders - who account for the problem debt.

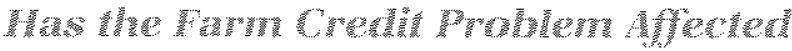

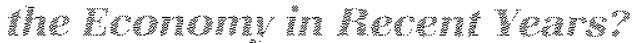

The spread between the interest rates on commercial paper and Treasury bills one measule of the spread between interest tates on private and public debt - - appears to mellect a risk plemitum on privaldy issued debt. Of the vears covered in chan 3 , the spread was largesf from 1980 through 1982, essentially one continuous period of economic recession." This rate spread also widened for a few months around the time of the finaneial crisis at the Continentallinois National Bank in May 1984, peshaps reflecting investors concern about the possible consequences of failure by Continental Illinois.

There is litte evidence, howerer, that the growing fam credit crisis since 1581 has had adverse dectson the economy. Real economic activity has ben rising since late 1982. Moreover, the spead between the commereial paper rate and the Treasuy bill fate genenally has narrowed following the shap lise in the faihue rate among agricullual banks that began in the second half of 1984 lehar 3 t. In fact, since mid-1984 the spread between interest lates on private and public debt instruments of similar maturty has been as low as at any period since 1978 . Thus, while this late spread refleets a risk promium, the risk premium does not appear to be signifoanty corelated with pol lems in agriculfure as suggested by sudies waning of a general financial orisis

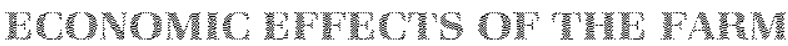

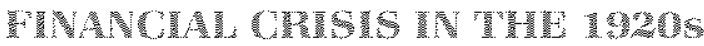

Since history frequently repeats itself we may learn something by looking back to similar problems in an eatier era. The agricultural sector of the U.S. economy experienced a financial crisis during the 1920 s that was similat in many rospects to tamels and fam Iender's' curent financial problems. To make this oxperience relevant for an analysis of the 1980 s. we fiest

\footnotetext{
The average spread between 1975 and 1980 was 52 basis points. This widened to an average of 140 basis points between 1980 and 1982. Since the beginning of 1983 , the average commercial paper Treasury bill rate spread has been 40 basis points, with a high of 95 basis points in June 1984 and a low of 7 basis points in July and August 1983
} 
Chart 3

\section{Short-Term Interest Rates}

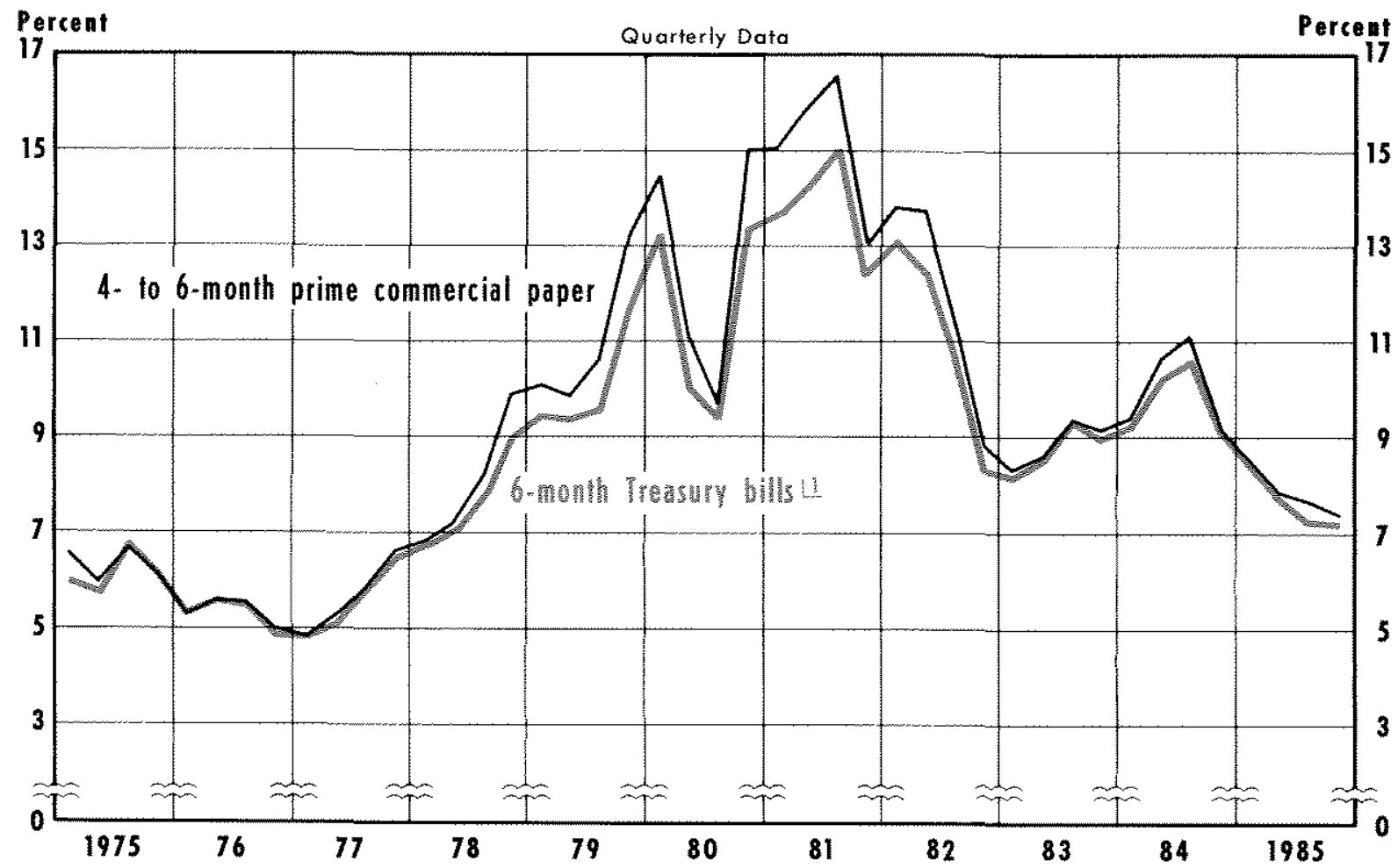

musl examine some of the important similarities and differences between the fam crises of the $1920 \mathrm{~s}$ and $1980 \mathrm{~s}$.

\section{U.S. Agriculture before World Whan I}

Agricklture accounted for much larger shares of employment and output in the U.S. economy before World War 1 than in the 1980s." In 1900, for example. about 41 percent of total employment was in the firm sector. The share of the labor force on farms was declining, falling to just under 30 percent by 1913 . In contrast the fam sector accounted for only 3 percent of civilian employment in 1981, the vear of the recent peak in farmland prices.

During the five vears ending in 1901, the dollar value of tarm output accounted for 23.5 percent of gross

Data used in this discussion are taken from the U.S. Department of Commerce (1975). private domestic product. By the five veas ending in 1921, that percentage declined to 14.5 percent. In contrast, fam output accounted for about 3 percent of gross private domestic product in 1981. These conlasts suggest that adverse developments in the farm sector should have had larger effects on the economy before World War I than in the 1980s.

The farm sector was the major export sector of the LS. economy before the was, with fam exports ac counting for 65 percent of the dollar value of all U.S. expots in 1901 . That share of total exports declined gradualy to 46 perent in 1913 , but rose again to 48 percent in 1920 . In 1981, agricultual products accounted for 18.6 percent of U.S. merchandise exports.

\section{The Crowing Importance of Credily for Agriculute}

Several developments made the avalability of credit more imponan for tarmes by the late 1800 s than it 


\section{Table 2}

\section{Farm Mortgage Debt and Its Distribution Among Lenders: 1910-29}

\begin{tabular}{|c|c|c|c|c|c|c|}
\hline Year & $\begin{array}{l}\text { rotal debl } \\
\text { (nitions? } \\
\text { or dollars) }\end{array}$ & 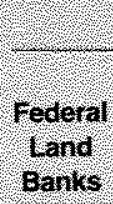 & $\begin{array}{l}\text { loint } \\
\text { stook } \\
\text { land } \\
\text { banks }\end{array}$ & $\begin{array}{l}\text { Percentag } \\
\text { ryie } \\
\text { insurance } \\
\text { companies }\end{array}$ & Cominercial & $\begin{array}{l}\text { hadividuals } \\
\text { land } \\
\text { oithers? }\end{array}$ \\
\hline 1010 & 50,207 & & & $120 \%$ & $127 \%$ & $75,3 \%$ \\
\hline 1913 & 4.347 & & & 127 & 155 & 718 \\
\hline 1915 & 4.990 & & & 13.4 & 16.0 & 716 \\
\hline 196 & 6.566 & $00 \%$ & & 146 & 154 & 693 \\
\hline 1920 & 8,46 & 3.5 & $07 \%$ & 115 & 143 & 70.0 \\
\hline 1925 & 9012 & 93 & 4.5 & 196 & 121 & 54.6 \\
\hline 1929 & 9756 & 12.1 & 67 & $21 \%$ & 107 & 48.5 \\
\hline
\end{tabular}

Uess han 01 petcent

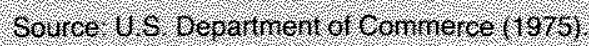

had been earlie: in U.S. history. In the easly 1800s, homesteaders could obtain land and become farmers relatively cheaply; by the late 1800 s. new famers had to buy land from other landowners. Farming also became nore capital-intensive as specialized machin erv and bujdings made fam operations more efficient.

Prio: to Wold War I, farm mortgage credit was available from commercial banks, life insurance companies, individuals, and others table 21. The category of "individuals and others," which accounted for 75 percent of farm mortgage cedit in 1910, included the fam mortgage loan companies that began operating in the late 1800 s. Mortgage loan companies generally were funded by investors in the eastern states. These companies emploved agents who worked in farm communities, accepted mo'tgage loan applications from famers and transmitted the loan applications to the mortgage companies for approval."

Most farm mortgage loans had maturities of thee to five vears." Maturties of fam mortgage loans tended to be shortest at comntercial banks; about half of these loans had maturities of one vear or less." Shorter loan

\footnotetext{
"Eichengreen (1984) and Otsen (1925).

"Farmers did not like the terms on which morgage credil was made avallable to them. They considered the interest rates on farm mortgage loans to be too high. Many farmers also considered the maturity of farm mortgage loans to be too short. See Eichengreen, Higgs (1971), and Stock (1984).

${ }^{13}$ Olsen, pp. 208-19.
}

maturities made famers more vulnerable to foreclosure by creditors. Although a famer experiencing temporaty financial distress ordinarily might be able to meet the payments on an outstanding mortgage loan, lenders might not renew the mortgage loan if it matured while a farmer was having a financial problem.

Farmers turned their complaints about the tems of credit available to them into an important political issue by the early 1900 s. Political initiatives by tarners resulted in the passage of the Federal fam Loan Act of 1916, which established the Fam Credit Banks under the ownership and supervision of the federal govenn ment. "That act also facilitated the development of joint-stock land banks, which were privately owned and managed fims that operated under the supervsion of the federal government. These two categories of federally supervised lending institutions made most of their farm mortgage loans with maturities of 33 to 35 years." Table 2 indicates that the Federal Land Banks and the joint-stock land banks did not become major farm lenders until the 1920 s.

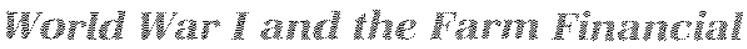

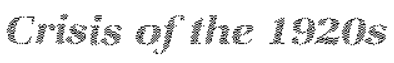

The fam financial crisis of the 1920 s resulted from the response of the U.S. agricultural sector to the disruption to agricultural production that occured in Western Europe during World War 1 . The nations of

\footnotetext{
${ }^{14}$ Olsen, p. 215.
} 


\section{Chart 4}

\section{Nominal Value of Farm Exports}

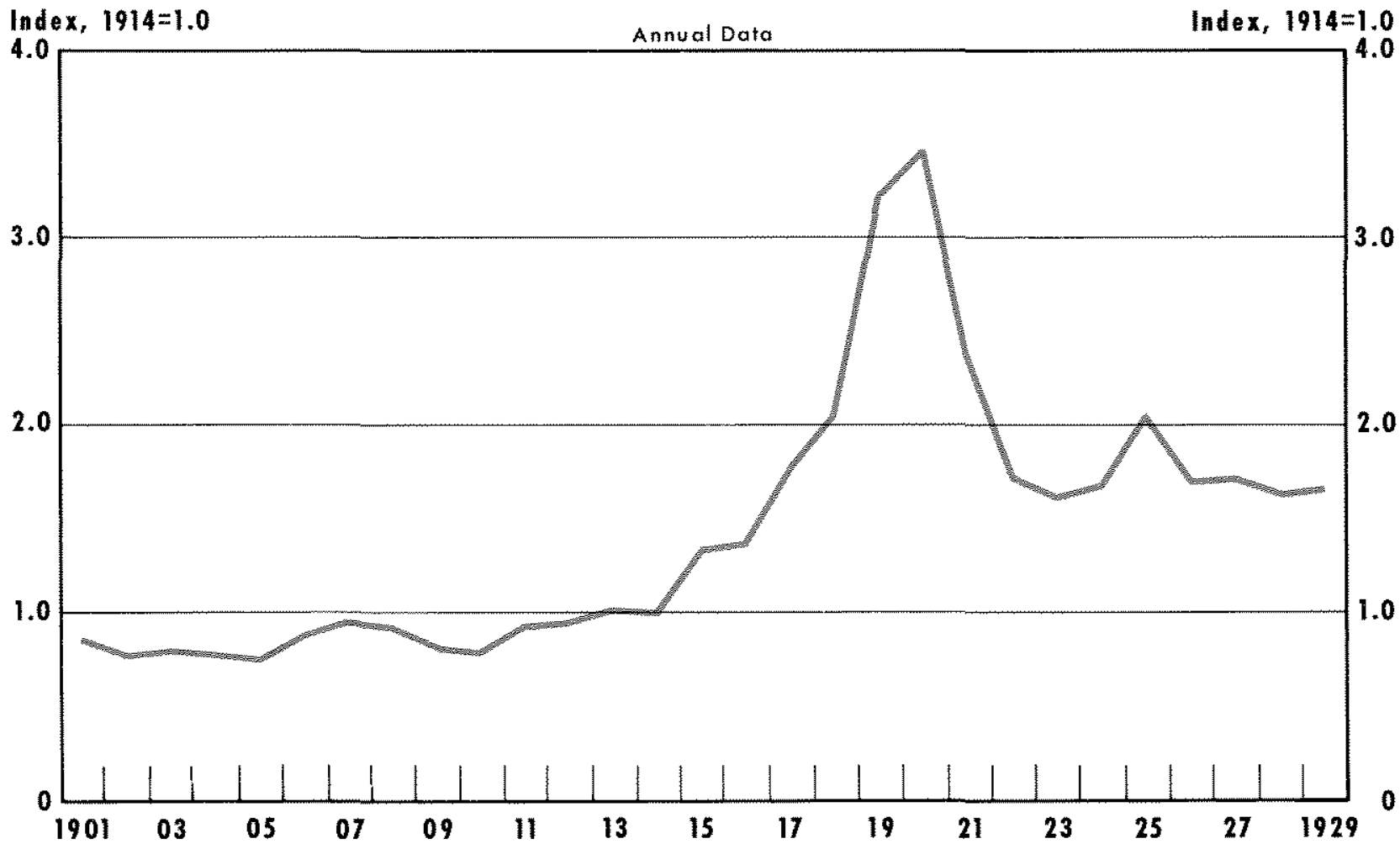

Western Europe increased their agricultum imports to replace lost production. This caused the dollat value of U.S. fam exports to rise sharply during the war and shorty thereafter chart 4 . Prices of farm products and famland rose sharply during these periods in response to the increase in foreign demand for U.S. farm products.

Farmers borrowed substantially during the war to buy land that was rising rapidly in value and to spend more on non-land inputs to expand production. Farm mortgage debt increased from $\$ 4.7$ billion on Januar 1, 1914, to $\$ 10.2$ billion on January 1 , 1921. Non-realestate farm loans at commencial banks rose from $\$ 1.6$ billion to 53.9 billion over the same period.

U.S. fam exports deched after the war, as fants in Westem Europe resumed production thart 4. The decline in export demand for U.S. fam products contributed to a reduction in farm prices relative to prices of industrial commodities. This ratio of farm to nonfarm prices peaked in 1920, then dechined shaply in
1921 (chart 5 ). The average price of farmand continued to rise through 1920 , then declined in each subsequent year through 1928 chart 6 ).

Declines in the prices of farm output and the value of farmland drove many famess into bankruptov and many agricultural banks into failure. From 1921 to 1929, an average of 635 banks failed per veat, conpared with an average of 88 bank failures per vear over the previous 20 vears.

Charts 5 and 6 compare the declines in prices of farm commodities and land in the 1920 s with those of the 1980s. These comparisons show declines much more severe than what has been observed so tar in the 1980 s. Fist, the relative price of fam output declined more in the 1920 s than in the 1980 s ichat 51 . Second, there were sharper declines in fammand prices, the collateral base for farm debt, after 1920 than after 1981 chart 6). Other things equal, these declines would have had much greater effects on the ability of fanthers to secure new short-term debt or sustain old debt in 
Chart 5

Trends in Relative Farm Prices in the 1920s and 1980s

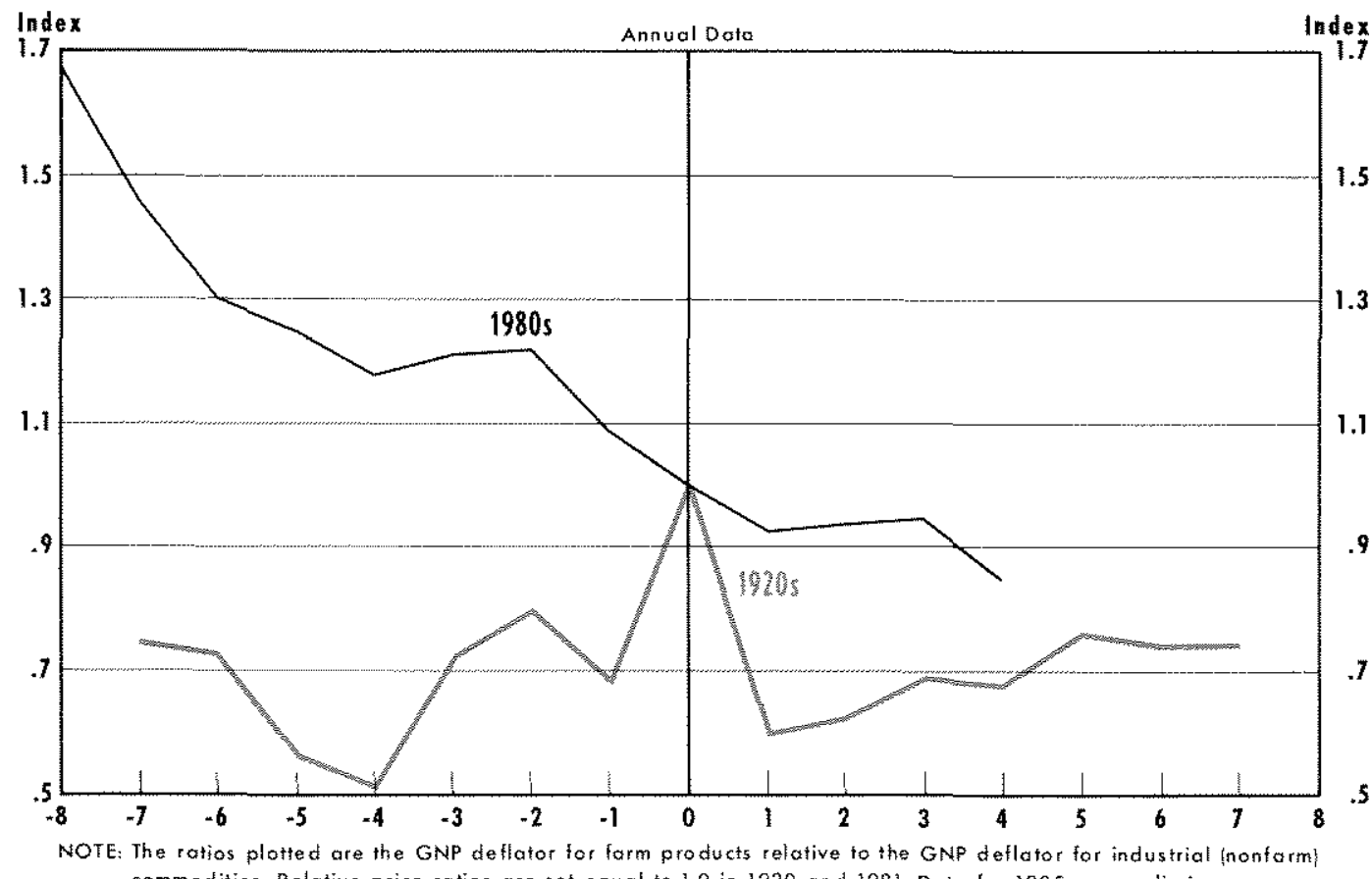
commodities, Relofive price rotios gre \$et equal to 1,0 in 1920 and 1981 . Doto for 1985 are preliminary.

\section{Chart 6}

Prices of Farm Real Estate per Acre Relative to Peak Prices in 1920 and 1981

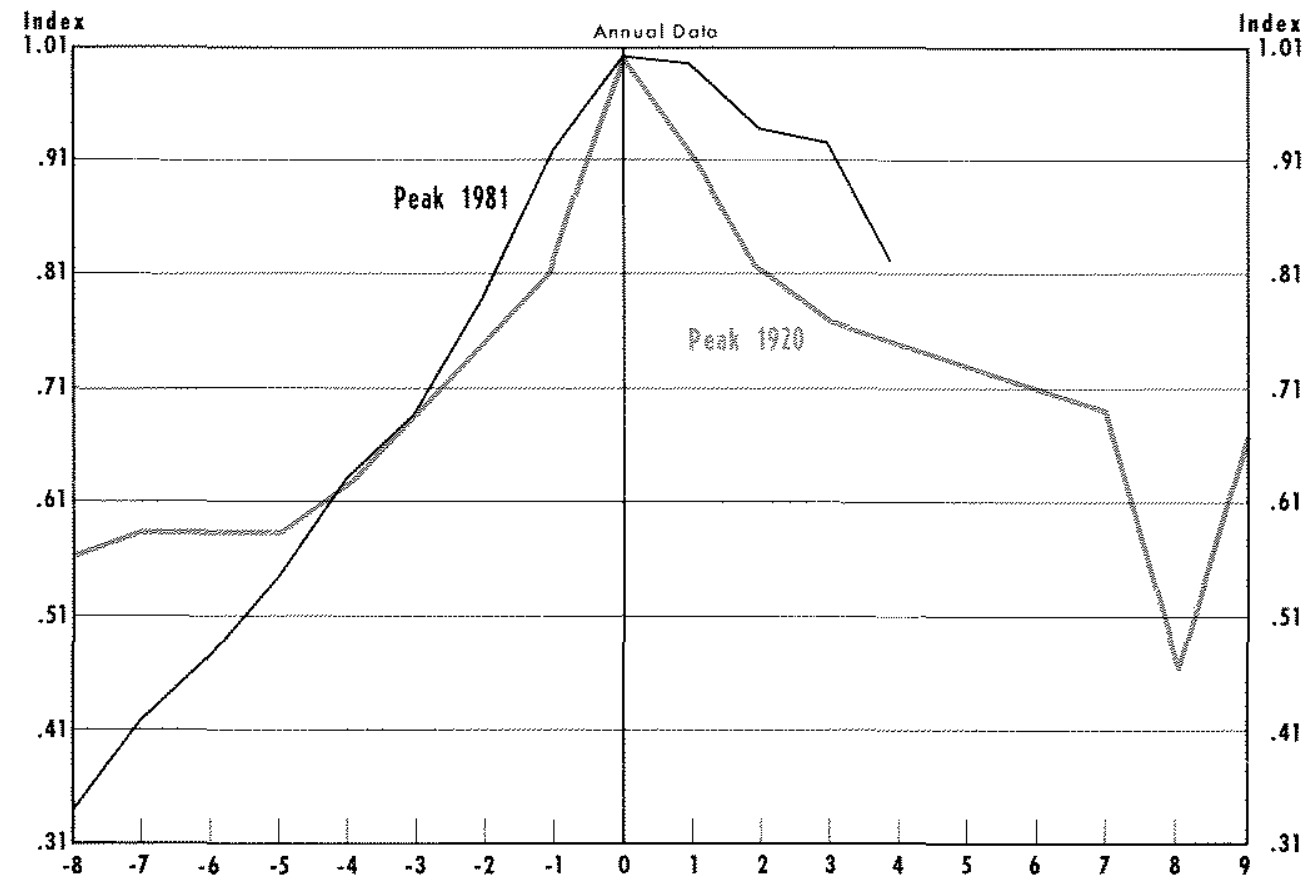


the 1920s. Finalv, with shorter maturities on most of the farm moltyage credit in the 1920s, the declines in farm prices and land values made famers more vulnemable to foreclosure then than now.

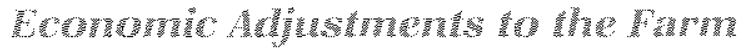

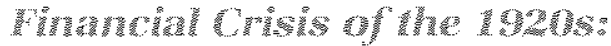

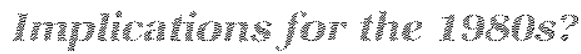

As noted previously, agriculture's larger share of total output in the 1920 s implies that problems in the fam sector would have had lager adverse effects on GNP and employment in the 1920s than in the 1980 s. Yet the 1920 s were vears of general economic prosperiv. Real GNP rose at a 4.2 percent annual mate from 1920 flmough 1929 , up from an average of 3 percent anmal growth over the prior 20 veas. The number of persons emploved grew at a 1.8 percent rate from 1920 through 1929, about the same rate as over the prior 20 veas. Although genemal economic growth might have been even stronger without aguiculure's problems, the actual economic perfomance cerainly meets or exceeds most historical norms.

Dectines in the prices of fam otitpat and famand in the 1920 as a had relatively small effects on economic activity in the fam sector. Although fam output fell shaply in 1921, the index of overal farm ontput had regained its previous peak by 1925. Farm ontput rose at a 1.4 percent amual late from 1925 through 1929 , while weal GNP rose at a 3.2 percent rate. Total employment in the fam sector essentially was unchanged in the 1920s: the growth of emplovment occured in the nonfarm sector.

How could such a severe deflation in the farm secm tor, with widespread fam bankruptcies, have such small effects on farm output? The answer involves the process of bankfuptcy in our capitalistic economic: svstem. When farmers go bankrupt, their land and equipment to not go out of production; these resonves instead are sold to other famers at reduced prices. It is the lower prices that make it profilable for other famers to buv the land and equipment even though prices for farm output are lower. Thus, through the process of bankruptcy, fam assets are repriced to levels low enough to make their continued use profitable for famers.

Finaly, if higher bank failure rates cause an increase in risk premiums on privately issued debt, this effect also should have been stronger in the 1920 s than in the 1980 s, especially since federal deposit insurance did not exist then. Despite the large number of bank failures during the 1920s, however, the spread be- tween the commercial paper rate and the vield on shortem Freasury securties did not widen during that decade tetat $7 \%$ Thus, the fimancial distress in the aglichlutul sector of the economy did not seem to produce an increase in risk premiums on plitately issted debt.

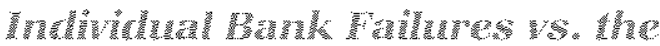 whidity of the Bunking Susten}

The pinary reason that the bank falures had such little influence on overall economic activity in the 1920 s was that the money supply grew fast enough to support growth in economic activity and to forestall liquictity problems in the banking svstem as a whole. Deposits in the and faled banks were simply transferred to solvent banks, whith no overall reduction in the money stock. Because the quantity of money is closely related to agregrate spending and economic activity, the growth in the money stock facilitaled growth in overall econonic activity char 81 . Alhough the money supply dropped shaply in 1921 , dung a recession after Wold War I, M1 idemand deposits plus cumency rose at about a 3 percent annual rate from dune 1921 through fune 1929. This increase facillated the economic glowth that occured over that period, in sharp contrast to the beginning of the Great Depression (1930-33), which saw the money stock decline at an 11 percent annual fate foht 8 ,

\section{CONGLSORE}

Many famers whin high matios of debt to assets wil go bankrupt unless the receve lagge government subsidies. Some economists have waned that rising farm bankruptcies will cause the fallue of many farm banks and possibly the fam Credit Svstem. Others even have suggested that fam loan losses are likely to produce a genuine financial crisis unless federal aid is provided.

The evidence presented in this aticle claes not support the argument that the fam financial crisis will adversev afect the entire econony. The financial problems of many famers have become semous since $\mathbf{1 9 8 1}$ primarily because the average price of farmand has dechned. The financial problems of tamers, however, have not increased the relative interest rates on

\footnotetext{
"The average spread in the 1920 s was 127 basis points. The lowest and highest average spreads were 73 basis points in 1928 and 231 basis points in 1920

${ }^{15}$ For a detailed analysis of how declines in the money stock were related to the Great Deoression, see Fredman and Schwartz (1963).
} 
Chart 7

Short-Term Interest Rates

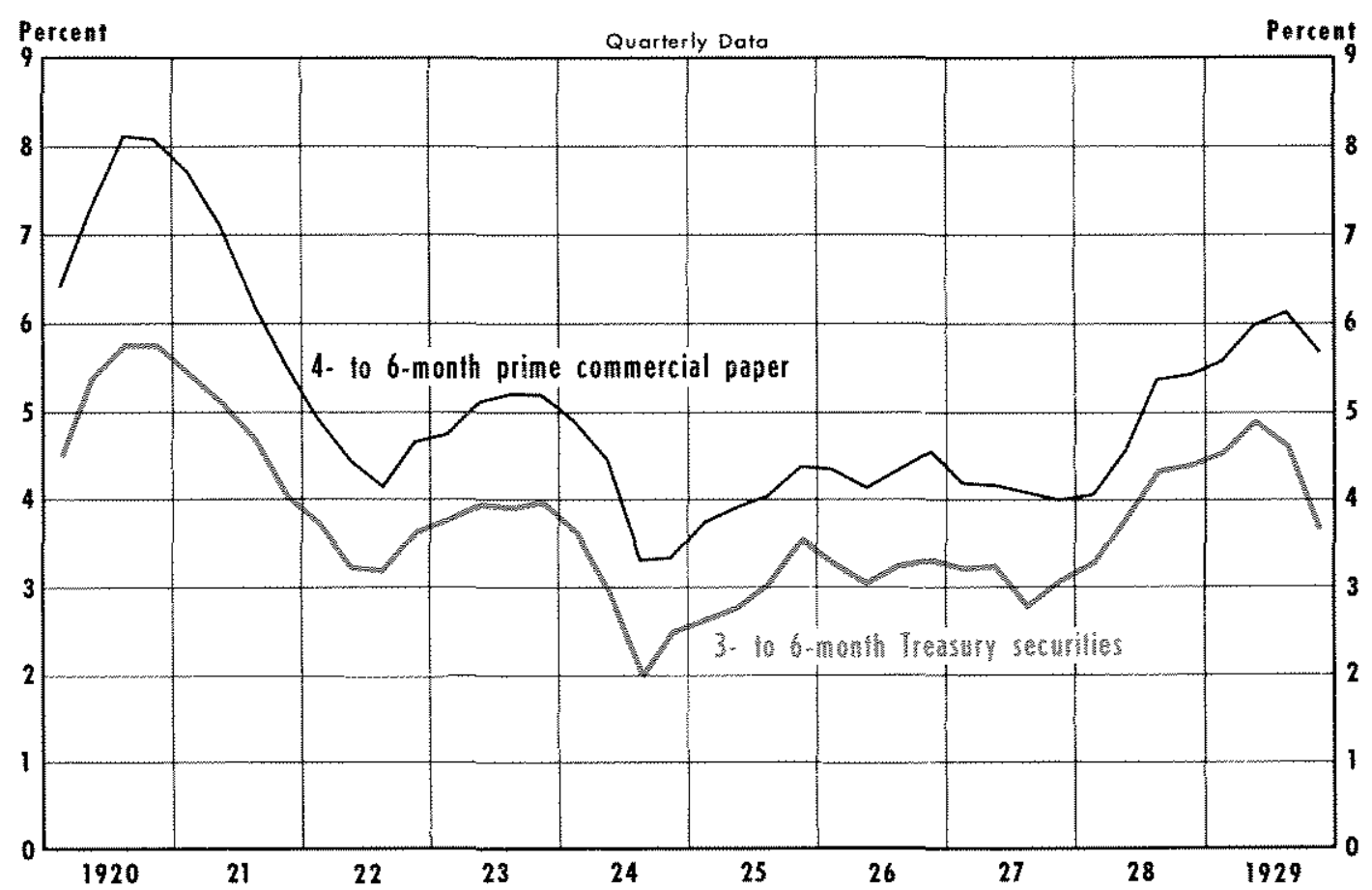

Chart 8

Changes in Gross National Product and the Money Stock

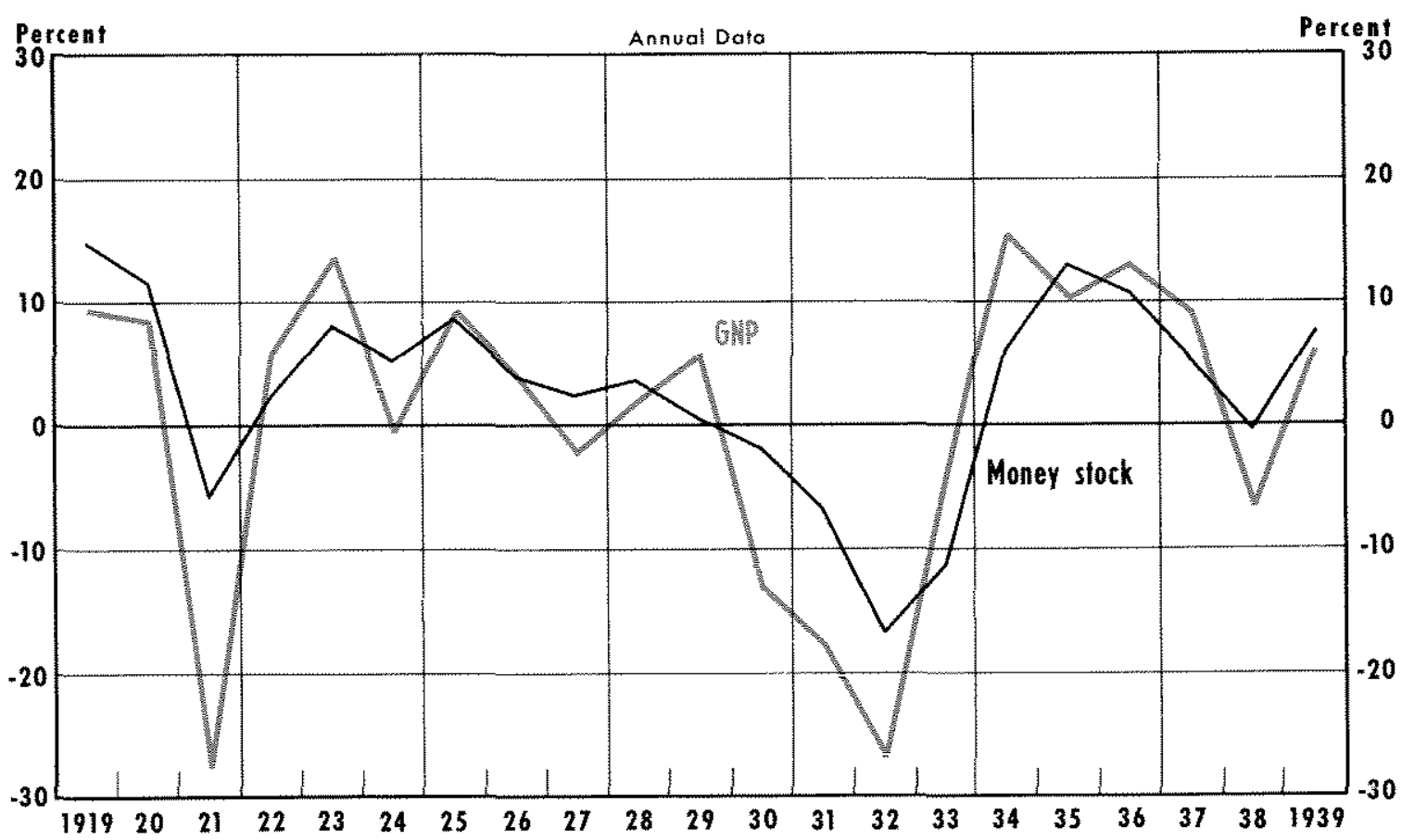


al) privately issued deht of slowed the growth of total output. Evidence from the 1920s, a period of similat crisis in the farm sector indicates that the farm financial crisis of that decade also had no advetse effects on the interest rates on privately issued debt or on overall economic growth. If we want to rationalize govenment support for farmers with high debt-to-assets ratios, such support should be sought on other grounds.

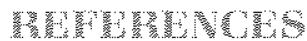

Belongia, Michael T., and Kenneth C. Carraro. "The Status of Farm Lenders: An Assessment of Eighth District and National Trends." this Review (October 1985), pp. 17-27.

Bullock, J. Bruce. "Farm Credit Situation: Implications for Agricultural Policy," FAPRI \#4.85, (Food and Agricultural Policy Research institute, March 1985).

Chase Econometrics. "Economic Impacts of a Farm Credit System Default," report to the Farm Credit Counci, October 1985.

Drabenstott, Mark, and Marvin Duncan. "Agriculture's Bteak Outlook." New York Times, August 14, 1985.

Eichengreen, Barry. "Mortgage interest Rates in the Populist Era,"
American Economic Review (December 1984), pp. 995-1015.

"The Farm Slide." Christian Science Monitor, August 20, 1985.

Friedman, Milton, and Anna J. Schwartz. A Monetary History of the United States, 1867-1960 (Princeton University Press, 1963).

Higgs, Robett. The Transformation of the American Economy, 18651914 (John Wiley and Sons, 1971).

Karr. Albert R., and Charles F. McCoy. "Farm Credit Will Need Massive U.S. Aid in 18 to 24 Months. Chief Regulator Says," Wall Street Joumal, September 6. 1985.

Olsen, Nils A. et al. "Farm Credit, Farm Insurance, and Farm Taxation," Agriculture Yearbook 1924, (U.S. Department of Agriculture, 1925), pp. 185-284

Schink, George R., and John M. Urbanchuk. "Economy-Wide Impacts of Agricultural Sector Loan Losses, "Wharton Econometric Forecasting Associates, July 1985.

Stock, James H. "Real Estate Mortgages, Foreclosures, and the Midwestern Agrarian Unrest, 1865-1920," Joumal of Economic History (March 1984), pp. 89-105

U.S. Department of Agriculture, Economic Research Service. The Current Financial Condition of Farmers and Farm Lenders, Agricul. tural Information Bulletin No. 490, March 1985.

U.S. Department of Commerce, Bureau of the Census. Statistical Abstract of the United States (U.S. Government Printing Office, 1985).

Historical Statistics of the United States (GPO, 1975). 